\title{
Evaluation of sampling and quenching procedures for the analysis of intracellular metabolites in $\mathrm{CHO}$ suspension cells
}

\author{
Judith Wahrheit," Jens Niklas, Elmar Heinzle \\ From 22nd European Society for Animal Cell Technology (ESACT) Meeting on Cell Based Technologies \\ Vienna, Austria. 15-18 May 2011
}

\begin{abstract}
Background
Metabolomics, aiming at the quantification of all extracellular and intracellular metabolites, is a valuable tool for characterizing, understanding and manipulating the physiology of mammalian cells. While extracellular metabolite analysis is well established, required quenching and extraction procedures for intracellular metabolite analysis in mammalian suspension cells are not yet routinely available. In this study a simple sampling and quenching protocol using ice-cold $0.9 \%$ saline as quenching solution [1] was tested on $\mathrm{CHO}$ cells. Quenching efficiency, preservation of cell integrity as well as cell separation and the necessity of washing steps were evaluated and possible sources of error are discussed.
\end{abstract}

\section{Materials and methods}

The antithrombin-III producing $\mathrm{CHO}$ cell line T-CHOATIII was cultivated in serum free CHO-S-SFM II medium (Gibco/Invitrogen, Carlsbad, CA, USA). Cells were kept in baffled shake flasks (Corning, Corning, NY, USA) in a shaking incubator (2 in. orbit, Innova 4230 , New Brunswick Scientific, Edison, NJ, USA) at $37^{\circ} \mathrm{C}$ with a constant $5 \%(\mathrm{v} / \mathrm{v}) \mathrm{CO}_{2}$ supply at $185 \mathrm{rpm}$. Quenching was performed by mixing $5 \mathrm{ml}$ of cell suspension with $45 \mathrm{ml}$ ice-cold $0.9 \%$ ice-cold saline as quenching solution (QS) [1]. Unless otherwise stated, sampling was done by centrifuging for $1 \mathrm{~min}$ at $1000 \mathrm{~g}$ followed by shock-freezing of cell pellets in a $\mathrm{CO}_{2}$-acetone bath. Intracellular metabolites were extracted from freeze-dried cell pellets using ice-cold 50\% acetonitrile [1]. Survival of the cells in the QS at $0^{\circ} \mathrm{C}$ was tested

\footnotetext{
* Correspondence: j.wahrheit@mx.uni-saarland.de
Biochemical Engineering Institute, Saarland University, 66123 Saarbrücken,

* Correspondence: j.wahrheit@mx.uni-saarland.de
Biochemical Engineering Institute, Saarland University, 66123 Saarbrücken, Germany
}

(c) 2011 Wahrheit et al; licensee BioMed Central Ltd. This is an open access article distributed under the terms of the Creative Commons Attribution License (http://creativecommons.org/licenses/by/2.0), which permits unrestricted use, distribution, and reproduction in any medium, provided the original work is properly cited.

\section{Results}

Cell integrity was maintained in ice-cold $0.9 \%$ saline for at least $30 \mathrm{~min}$. Centrifugation at $1000 \mathrm{~g}$ for $1 \mathrm{~min}$ led to $50 \%$ cell loss during sampling. Sampling at higher RCF increased cell yield to $65 \%$. However, sampling at RCF higher than $2000 \mathrm{~g}$ did not further increase cell yield but seemed to affect cell viability. Unchanging cell diameter and morphology before and after quenching and during incubation at $0^{\circ} \mathrm{C}$ indicated that no osmotic stress and no biased selection of cells during centrifugation occurred. Contamination with culture medium was found relatively low even without any washing steps. Less than $0.25 \%$ pyruvate and lactate and less than $0.1 \%$

after sampling at different relative centrifugal forces viability and cell morphology of cells re-suspended in QS were checked during incubation at $0^{\circ} \mathrm{C}$ using an automated cell counter (Countess, Invitrogen, Karlsruhe, the culture medium was investigated without washing and after applying different washing strategies. Cell pellets were either re-suspended in $50 \mathrm{ml}$ QS or rinsed $50 \mathrm{ml}$ QS followed by another centrifugation step. lysed and compared to the initial sample. Quenching amounts at $0^{\circ} \mathrm{C}$. Lactate dehydrogenase activity was quenching $\left(37^{\circ} \mathrm{C}\right)$ after cell permeab Triton-X-100 [2]. Intracellular citrate, $\alpha$-ketoglutarate, pyruvate, succinate, lactate and fumarate were quantified in cell extracts after incubation of quenched cell suspensions at $0^{\circ} \mathrm{C}$ for 0,5 or $10 \mathrm{~min}$. 
glucose compared to the amounts measured in the extracellular medium of the cell suspension were found after quenching. Citrate found in the initial sample was not detected after quenching in any of the samples with or without washing. Furthermore, after washing by rinsing or re-suspending the cell pellets no glucose and less than $0.2 \%$ pyruvate and lactate could be detected. Washing by resuspending did not yield better results than rinsing the cell pellet but can possibly lead to cell damage and leakage of intracellular metabolites as indicated by traces of fumarate detected in the sample. The inclusion of washing steps further decreases cell yield. Cell loss after rinsing the cell pellet was very low $(48 \%$ cell recovery compared to $56 \%$ without washing). In contrast, washing by re-suspending the pellet led to a tremendous cell loss; only $19 \%$ of the initial cell number could be recovered. In quenched cells enzyme activity was efficiently stopped as shown by comparing lactate dehydrogenase activity in quenched cells (specific activity $0.33 \pm 1.1 \mathrm{pmol} /(\mathrm{cell} \times \mathrm{h}))$ and control cells kept at $37^{\circ} \mathrm{C}(15.17 \pm 0.19 \mathrm{pmol} /($ cell $\times \mathrm{h}))$. Increasing concentrations of pyruvate, lactate and fumarate after $10 \mathrm{~min}$ incubation of quenched cell suspensions at $0^{\circ} \mathrm{C}$ indicate that metabolism is not completely stopped at $0^{\circ} \mathrm{C}$. However, metabolic activity seemed to be sufficiently slowed down within the first $5 \mathrm{~min}$ of incubation where no significant change of intracellular metabolites was observed.

\section{Conclusions}

Ice-cold $0.9 \%$ saline proved to be a suitable QS maintaining cell integrity and cell morphology. Sampling via centrifugation at RCF higher than $2000 \mathrm{~g}$ seemed to affect cell viability and should be avoided. By using a tenfold excess of QS compared to the sample volume rapid cooling of the sample could be achieved and contamination with culture medium was found relatively low even without any washing steps. Carryover of extracellular metabolites can be further reduced by rinsing the cell pellet with an excess of QS. Washing by re-suspending the cell pellet diminished cell yield tremendously and can possibly lead to cell damage resulting in leakage of intracellular metabolites. It is therefore not suitable. In quenched cells enzyme activity was efficiently halted within the first $5 \mathrm{~min}$ of incubation at $0^{\circ} \mathrm{C}$ indicating sufficient quenching of metabolic activity for the analysis of intracellular metabolites with lower turnover. Sampling and washing should therefore be completed within the first $5 \mathrm{~min}$ after quenching.

Published: 22 November 2011
References

1. Dietmair S, Timmins NE, Gray PP, Nielsen LK, Krömer JO: Towards quantitative metabolomics of mammalian cells: Development of a metabolite extraction protocol. Anal Biochem 2010, 404:155-164.

2. Niklas J, Melnyk A, Yuan Y, Heinzle E: Selective permeabilization for the high-throughput measurement of compartmented enzyme activities in mammalian cells. Anal Biochem 2011, doi:10.1016/j.ab.2011.05.039.

\section{doi:10.1186/1753-6561-5-S8-P82}

Cite this article as: Wahrheit et al.: Evaluation of sampling and quenching procedures for the analysis of intracellular metabolites in CHO suspension cells. BMC Proceedings 2011 5(Suppl 8):P82.

\section{Submit your next manuscript to BioMed Central} and take full advantage of:

- Convenient online submission

- Thorough peer review

- No space constraints or color figure charges

- Immediate publication on acceptance

- Inclusion in PubMed, CAS, Scopus and Google Scholar

- Research which is freely available for redistribution

Submit your manuscript at www.biomedcentral.com/submit 